\title{
Teaching innovations in Asian higher education: perspectives of educators
}

\author{
T.M. Wong \\ The Chartered Institute of Linguists Hong Kong Society, Kowloon, Hong Kong
}

\begin{abstract}
Purpose - The purpose of this paper is to identify the teaching innovations that have been implemented in higher education institutions in Asia and the perspectives of educators on them.

Design/methodology/approach - Semi-structured interviews were conducted with 28 educators who were affiliated with 23 higher education institutions in ten Asian countries/regions. The interviews covered information about the teaching innovations of the participants' institutions, the characteristics of the innovative practices and the participants' views on them. The relationships between the characteristics of institutions and their teaching innovations were also examined.

Findings - The results showed that the teaching innovations included two main categories, namely, those which involved the use of advanced technologies and those which did not. The innovations that involved the use of advanced technologies were mainly from larger institutions, while the other category was mainly from smaller ones and had been practised for less than 1.5 years. Differences were also identified between the two categories in terms of the aims and importance of innovations, innovative features, the evaluation of innovations and improvements needed for them.

Originality/value - The results highlighted that technology is only one of the many aspects of teaching innovations, which is different from the view prevailing in the literature. They also suggested that differences in the scale of institutions (in terms of number of students) possibly influences the kind of teaching innovations adopted.
\end{abstract}

Keywords Innovation, Asia, Tertiary education, Technology, Teaching, Higher education institutions

Paper type Research paper

\section{Introduction}

Innovation has been regarded as the key for higher education institutions to respond to technological advances and the changes in social and cultural values (Ahmad, 2015). Educational institutions must be "change-resilient" and continuously improve their practices and methods of delivery (Weller and Anderson, 2013). In the educational context, innovation often lies in teaching, with "newness" as an essential ingredient (Hauser and Hauser, 2011). It can occur in forms such as the use of new methods and novelty in content, pedagogy or curricula (Lee, 2011; Smith, 2011; Zhu, 2013).

Teaching innovation has been understood and practised in various ways. Among them, technology is an element commonly found, and is often adopted as a support mechanism for the delivery of new teaching methods (Zhu et al., 2013). Examples include cloud-based applications and electronic whiteboards (Lee, 2011); student response systems in the classroom (Choi et al., 2018; Lantz, 2010); mobile devices for in-class and out-of-class activities (Li, Lee, Wong, Yau and Wong, 2018); and learning analytics to evaluate and improve teaching effectiveness (Wong, 2017). Zhu et al. (2013) specified technological competence as one of the four major competencies required in innovative teaching, in addition to learning, social and educational competence. In Salmon's (2014) framework

(C) T.M. Wong. Published in Asian Association of Open Universities Journal. Published by Emerald Publishing Limited. This article is published under the Creative Commons Attribution (CC BY 4.0) licence. Anyone may reproduce, distribute, translate and create derivative works of this article (for both commercial and non-commercial purposes), subject to full attribution to the original publication and authors. The full terms of this licence may be seen at $\mathrm{http} / /$ creativecommons.org/licences/by/4.0/legalcode
Teaching innovations

Received 8 December 2018 Revised 19 December 2018 Accepted 20 December 2018

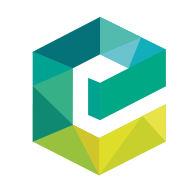

Asian Association of Open Universities Journal Vol. 13 No. 2, 2018 pp. $179-190$ Emerald Publishing Limited 2414-6994 
AAOUJ

13,2

for learning innovation, technology is a major dimension for categorising different innovative strategies.

Asia is a continent which places a strong emphasis on innovation. The Harvard Business Review (2017) highlighted the top 10 countries in the Bloomberg 2017 Innovation Index, among which were three Asian countries. In the OECD's (2014) report on measuring innovation in education for countries/regions all over the world, 80 per cent of the Asian countries/regions covered in the report got an overall rating for education innovation which was above the average in terms of the changes in educational practices. However, there has also been criticism of the cultural and social factors in Asian higher education, which may hinder new thinking and innovation (Altbach, 2010). Li, Ye and Wong (2018) found that the development of learning analytics was diverse in various higher education institutions in Asia, with some working actively on it to innovate their education delivery and some encountering difficulties because of resistance to change. The cultivation of teaching innovations in Asian higher education therefore varies widely.

This study aims to explore the teaching innovations in Asian higher education from the perspectives of educators in relevant tertiary institutions. It identifies the teaching innovations that have been implemented in Asian higher education institutions, and examines the relationships between the innovation practices and the characteristics of the institutions. Specifically, this study addresses the following research questions:

$R Q 1$. What teaching innovations have been implemented in higher education institutions in Asia?

RQ2. What are the characteristics of those teaching innovations?

RQ3. What are the views of Asian tertiary educators on the teaching innovations, their future development and ways of evaluating them?

RQ4. What are the relationships between the characteristics of institutions and their teaching innovations?

\section{Literature review}

The literature relevant to teaching innovations has covered a broad range of areas, from the perceptions of teaching innovation to the factors in successful innovation practices, the specific innovations implemented in education institutions and their effectiveness.

Zhu (2013) investigated the extent of innovation in teaching and learning in the schools in two Asian cities (Beijing and Hong Kong) as perceived by their teachers and students. On the dimensions of technology, pedagogical orientation and cultural environment, they found an overall high level of technology use in the schools, but a low level of its use for collaboration and a low level of pedagogical innovation. It was concluded that the teachers and students did not perceive their schools as innovative, despite the existence of innovative elements in their teaching and learning strategies. Hofman et al. (2011) presented the differences between school leaders and teachers in their perceptions of hindrances to innovations. They showed that teachers regarded the factors - such as the lack of sufficient support, the lack of proper educational tools and the unfit organisational structure for the innovation - as more of a bottleneck than the school leaders did. They claimed that such kinds of bottlenecks would be more visible in institutions in developing countries with a shortage of resources and teachers.

Another category of related studies has focussed on the drivers of successful innovations. Smith (2011) identified external and institutional rewards, as well as recognition, as the key drivers of innovation in learning and teaching. Support from senior management and the availability of technical support, for both short-term and long-terms projects, are also important for the sustainable development of institutional innovation. Lunde and Wilhite (1996) identified 
the characteristics of teachers who are innovative, showing that passion, persistence in improvement, being attentive to students, the use of active learning, risk taking and keeping themselves vital are the key characteristics. Lee (2011) investigated how teaching innovation and the integration of information technology into teaching contribute to learning effectiveness. The results showed that both these factors had direct, positive and significant effects on students' learning effectiveness.

The success factors for teaching innovations have also been presented in relevant frameworks. Hazen et al. (2012) proposed a framework for the dissemination of education innovations. For the target groups to adopt and routinely practise an innovation, this framework emphasises the awareness of innovation, as well as the characteristics of innovation (e.g. materials, methods, and attributes), target groups (e.g. personality and experience) and the environment (e.g. infrastructure, reward system and class size). Salmon (2014) offered a strategic framework for enhancing learning and pedagogical innovation, including two dimensions - the adoption of current/new learning design and technology, and the focus on current/new missions, markets and contexts. It was claimed that this framework facilitates the engagement of institutional members in an achievable and acceptable innovation agenda.

As far as specific innovative teaching practices are concerned, Evans et al. (2016) found that their blended curriculum in pre-clinical epidemiology and biostatistics had positive effects on both student satisfaction and their mastery of core materials. Foster and Yaoyuneyong (2016) implemented a flipped classroom in two business classes; and positive feedback was received from students, who said that they recognised the value of the process, improved their communication skills, and became better prepared for the workplace environment. $\mathrm{Neo}$ and $\mathrm{Neo}$ (2001) reported the use of multimedia technology as a teaching and learning strategy in a problem-based learning environment, and students expressed positive attitudes to the innovation in terms of enjoying the teamwork, and noted that it could enable them to think critically and be active in their participation. Drummond et al. (2016) combined video and simulation in teaching medical students, which also had a positive impact on teaching and learning. Finally, Kampylis et al. (2013) reviewed cases of ICT-enabled innovation for learning from Europe and Asia. The Asian cases include one from Hong Kong on exploring suitable modes and support measures for the development of sustainable, transferable and scalable e-learning solutions; a case in Japan on promoting student-centric education by creating a large learner community; a Singaporean case on engaging its entire school population in self-directed and collaborative learning with ICT; and a South Korean case on developing accessible and easy-to-use digital textbook contents by leveraging the potential of mobile devices and social network tools.

The relevant literature reveals the divergence of teaching innovations in Asia. In particular, technology was a major element in the innovation practices, but there were also practices which did not involve the adoption of technology. In addition, there were cases in which the use of new technology was mistaken for educational innovation (Salmon, 2014), and various stakeholder groups may have different, or even contradictory, perceptions of innovation practices (Hofman et al., 2011; Zhu, 2013). There is therefore a need for further work on this area to investigate the diverse aspects of teaching innovations in Asian higher education.

\section{Methodology}

Semi-structured interviews were conducted with a total of 28 educators working in higher education institutions in Asia, with the aim of collecting information on the innovative teaching practices in their institutions and their views on them. About 60 per cent of the interviewees were academics involved in frontline teaching, 25 per cent were in management and the remainder were IT experts, teaching and learning officers and 
AAOUJ 13,2

182

research support staff. The interviewees were affiliated to 23 institutions, of which 26 per cent were private and 74 per cent were publicly-funded. About 40 per cent of the institutions had more than 10,000 full-time students. All the institutions were located in Asian countries/regions, including Hong Kong, Indonesia, Japan, Mainland China, Malaysia, Pakistan, Singapore, Taiwan, Thailand and the Philippines.

The interviews had three parts, namely, factual information - aims, start date, and context of implementation - on the most recent teaching innovation in which an interviewee had been involved; the features of the innovation and its evaluation method; and the views of the interviewees on the teaching innovation in terms of its importance, difficulties encountered, possible improvements and the effectiveness of the evaluation method. The data were then coded with categories of themes identified for each question. Descriptive statistics, such as the frequency distributions and cross-tabulations, were performed to explore patterns in the findings.

\section{Findings}

\section{The nature of innovations and their implementation}

Types of innovation. The teaching innovations described by the interviewees can be categorised into two main groups - those that involved the use of technology and those that did not. Table I shows the teaching innovations involving the use of advanced technologies, most of which were internet- or mobile-oriented. The participants emphasised that real-time communication is a key advantage. MOOC and flipped classrooms, as two examples relying heavily on the internet, have become popular and have demonstrated their effectiveness in improving students' learning performance.

Table II lists the innovations where technology was not a core part. The most frequent one was related to students' active learning, followed by the use of videos in classroom teaching and interdisciplinary collaboration between students. A characteristic of this category of innovation is that it not only focussed on students' learning but also other aspects such as teaching and students' feedback.

Figure 1 presents the level of the teaching innovations, more than half of which were implemented at a course level. The innovations covered a broad range of 19 disciplines, such

Table I.

Teaching innovations that involve advanced technologies
Teaching innovations

Use of online materials or software tools

Use of mobile technology

Massive open online course

Flipped classroom

Simulation

Total
Table II.

Teaching innovations that did not mainly involve advanced technologies
Teaching innovations

Freq.

Active learning

Use of videos in classroom teaching

Interdisciplinary collaboration between students

Sharing of teaching and learning resources among teachers

Survey of student feedback

Mutual class observation among teachers

Total 3 
as accounting and finance, arts and culture, computer science, economics, engineering, law, mathematics and nursing. This is consistent with the situation described in the literature, namely, that teaching innovations are often employed on a discipline-specific rather than an institution-wide scale, possibly due to disciplinary differences in study content.

Figure 2 shows the number of years that the teaching innovations had been implemented, with the average being 2.3 years. About half of the innovations had been practised for 1.5 years or less. Also, about 20 per cent had been practised for more than three years.

Aims of innovations. Table III shows the aims of the innovations as reported by the participants. The innovations which were technology-oriented put more emphasis on the cognitive and academic aspects of learning (e.g. understanding of subject knowledge and preparation for exams), as well as the facilitating conditions (e.g. students' participation
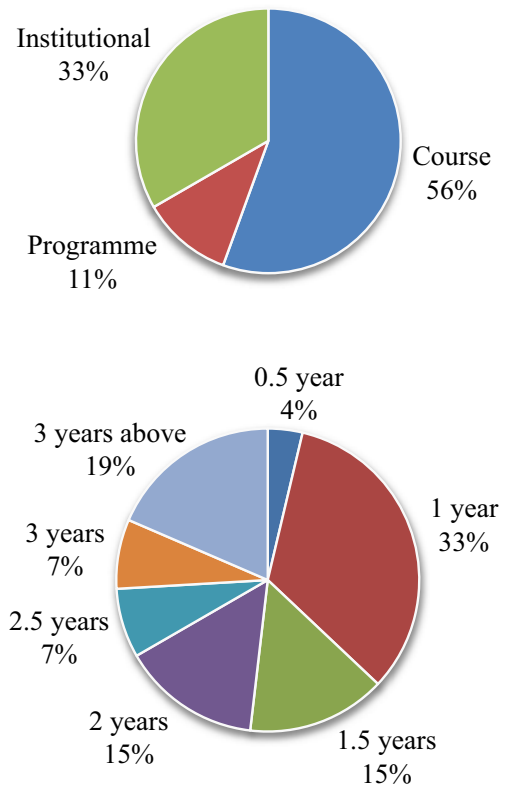

\section{Teaching innovations}

183
Figure 2.

Number of years that the teaching innovations had been implemented

\begin{tabular}{|c|c|c|c|}
\hline Technology-oriented innovations & Freq. & Non-technology-oriented innovations & Freq. \\
\hline Increase students' participation & 7 & Cultivate students' independent learning ability & 2 \\
\hline Check students' understanding & 6 & Facilitate collaboration among students & 2 \\
\hline Enhance teacher-student interaction & 4 & $\begin{array}{l}\text { Prepare students for adapting to learning in the } \\
\text { institution }\end{array}$ & 2 \\
\hline Help students to solve problems & 2 & Provide students with better services & 2 \\
\hline $\begin{array}{l}\text { Prepare students for exams or the work } \\
\text { environment }\end{array}$ & 2 & Support teachers' sharing of teaching materials & 1 \\
\hline Increase mobility in learning & 2 & Develop students' creativity & 1 \\
\hline Stimulate students' interests & 1 & Assist students in learning from their peers & 1 \\
\hline $\begin{array}{l}\text { Enable students to understand their own } \\
\text { progress }\end{array}$ & 1 & Meet market needs & 1 \\
\hline Help students to improve their English & 1 & & \\
\hline Total & 26 & Total & 12 \\
\hline
\end{tabular}

Table III. Aims of innovations

Figure 1.

Level of teaching innovations 
AAOUJ 13,2

184

and teacher-student interactions). The non-technology-oriented ones, on the other hand, were more related to the non-academic and non-cognitive aspects of students' development, such as the ability for independent learning and creativity.

Features of innovations. Table IV presents the features of the innovations, where distinctive patterns were found in the two categories. The technology-oriented innovations featured the higher usability of technology and better students' learning (e.g. learning motivation, understanding and in-class discussion), while the non-technology-oriented ones focussed on the facilitation of teaching and students' collaboration.

Evaluation of innovations. Table V reports how the innovations were evaluated. There were no clear patterns between the two categories. The most common method for evaluating the innovations was feedback from students, such as questionnaire surveys and interviews with individual students or focus groups. This was followed by students' academic performance, and evaluations by different stakeholders, such as teachers, management and the government. Some participants reported that no evaluation was conducted for the innovations. Also, some of them pointed out that no direct evaluation was conducted specifically for the innovations, with the evaluation being carried out together with other student experience as a whole, e.g. students' overall evaluation of their learning experience.

\section{Views on teaching innovation}

Importance of the innovations. Table VI lists the importance of the innovations from the view of the participants. Despite the various aims and features of the innovative practices,

\begin{tabular}{|c|c|c|c|}
\hline \multicolumn{2}{|l|}{ Technology-oriented innovations } & \multicolumn{2}{|l|}{ Non-technology-oriented innovations } \\
\hline Feature & Freq. & Feature & Freq. \\
\hline Higher technological usability & 4 & $\begin{array}{l}\text { Teachers reflected on their own teaching } \\
\text { and facilitate their teaching }\end{array}$ & 6 \\
\hline Improved students' learning motivation & 3 & More cross-disciplinary collaboration & 5 \\
\hline $\begin{array}{l}\text { Allowed checking of students' } \\
\text { understanding }\end{array}$ & 2 & $\begin{array}{l}\text { Students were better prepared for adapting to an } \\
\text { institution's learning environment }\end{array}$ & 1 \\
\hline More discussion in class & 2 & Students becoming teachers & 1 \\
\hline Greater mobility in learning & 2 & Improved students' satisfaction & 1 \\
\hline $\begin{array}{l}\text { Enabled students to understand their } \\
\text { own progress }\end{array}$ & 1 & Developed students' better creativity & 1 \\
\hline More teacher-student interaction & 1 & More updated teaching materials & 1 \\
\hline More time for problem-based learning & 1 & Saving money for students & 1 \\
\hline Developed students' active learning & 1 & & \\
\hline Strengthened teacher-student bonding & 1 & & \\
\hline $\begin{array}{l}\text { Students becoming more familiar with } \\
\text { the work environment }\end{array}$ & 1 & & \\
\hline Total & 19 & Total & 17 \\
\hline
\end{tabular}

Method

Students' feedback (e.g. surveys, individual or focus group interviews)

Students' academic results

Teachers' feedback (e.g. observation and evaluation)

Table V. Methods for evaluating innovations
Students' online record

Management's evaluation

Government's monitoring

Total 
Student-centred innovations

Engaged students in learning

Achieved greater mobility in learning

Cultivated students' independent learning ability

Had more student-teacher interaction

Allowed more time for in-class discussion

Catered for more students' needs

Enabled students to understand their own progress

Facilitated students to remember basic knowledge

Helped students to get through the process of dissertation writing 1

Prepared students for exams or the work environment 1

Served as a bridging course

Developed students' creativity

5

2

2

2

1

1 1

Teacher-centred

Helped to check students' understanding

Helped teachers to reflect on their own teaching

Provided better services to students

Offered alternative instructional strategies

Others

Achieved quality assurance

Demonstrated the effectiveness of innovation for adoption in other disciplines

Fitted the context of the country

Total
185

Table VI.

Participants' views on the importance of the innovations

their importance mainly revolved around students' learning. Student engagement was most frequently mentioned, followed by mobility in learning, independent learning ability and student-teacher interaction. There were also teacher-centred points, such as checking students' understanding and teachers' reflection on their teaching. The results suggest that the participants regarded students as the focus of teaching innovations.

Difficulties in implementing the innovations. Table VII presents the participants' difficulties in implementing the innovations. Despite the difficulties related to students

Difficulty

Student-centred

Students' lack of motivation

Students' limited participation

Students' negative perception

Teacher-centred

Teachers' lack of required knowledge or skills

Teachers' lack of motivation

Teachers' negative perception

Teachers' concern about extra effort

Others

Technological problems

Table VII.

Management problems

ants' views on

Problems occurring during implementation difficulties in

Lack of government support

Total

implementing the innovations 
AAOUJ 13,2

186

(e.g. their lack of motivation and limited participation), more challenges lay in the teachers' aspects such as their lack of required knowledge and skills and their motivation to implement the innovations. In addition, technological and management problems were frequently mentioned. The participants' feedback thus showed a broad range of challenges to be tackled for achieving the desirable outcomes of the teaching innovations.

Ways of improving the innovations. Table VIII shows the participants' views on ways to improve the innovations. Between the two categories, the technology-oriented innovations were viewed more frequently as having room for improvement in, for example, student participation, interaction and the use of technology. The non-technology-oriented ones involved, for instance, catering for students' diversity, having suitable facilitators and learning activities, active learning, catering for the emotional needs of students, and changing students' mindset.

Preferred ways of evaluation. Table IX presents the participants' preferred ways of evaluating the innovations, which may be different from the ones in practice in their institutions. Both groups regarded student feedback, academic performance and teachers' evaluation as the best indicators of the success of the innovations. The technology-oriented group also included indicators such as usability and students' online records of technology use. For the non-technology-oriented group, evaluation by stakeholders including parents, management and industry representatives was pointed out.

\section{The relationships between the teaching innovations and other factors}

Table X presents the relationships between the teaching innovations and factors including the scale of institutions and the length of implementing the innovations. The institutions

\begin{tabular}{lcll}
\hline \multicolumn{1}{c}{$\begin{array}{c}\text { Technology-oriented innovations } \\
\text { Ways to improve the innovations }\end{array}$} & Freq. & Ways to improve the innovations & Freq. \\
\hline $\begin{array}{l}\text { Promote student participation } \\
\text { Enhance interaction (teacher-student and }\end{array}$ & 6 & & Cater for students' diversity \\
student-student) & 4 & Select suitable facilitators & 2 \\
Improve teachers' use of technology & 3 & Pay more attention to learning activities & 2 \\
Reduce teachers' workload & 2 & Change students' mindset & 1 \\
Develop more multimedia materials & 2 & Offer rewards to students & 1 \\
Understand teachers' needs & 2 & Cooperate with other institutions & 1 \\
Help students to understand better what to do & 2 & Promote more active learning & 1 \\
Apply the innovation in different disciplines & 1 & Cater for students' emotional needs & 1 \\
Conduct more relevant research & 1 & & \\
Offer more funding & 1 & & \\
Total & 24 & Total & 11 \\
& & &
\end{tabular}

\begin{tabular}{lrlr}
\hline \multicolumn{1}{c}{$\begin{array}{c}\text { Technology-oriented innovations } \\
\text { Ways of evaluation }\end{array}$} & \multicolumn{2}{c}{$\begin{array}{c}\text { Non-technology-oriented innovations } \\
\text { Freq. }\end{array}$} \\
\hline Student feedback & 9 Student feedback & 4 \\
Students' academic performance & $5 \quad$ Students' academic performance & 3 \\
Evaluation by teachers & $4 \quad$ Evaluation by teachers & 2 \\
Students' products & 1 Evaluation by parents & 1 \\
Students' online records & 1 Evaluation by management & 1 \\
Usability tests & $1 \quad$ Evaluation by industry representatives & 1 \\
Comparison (between experimental and control group) & 1 & & 12 \\
Total & $22 \quad$ Total &
\end{tabular}

Table VIII.

Ways of improving the innovations
Offer more funding

.


where the innovations were implemented were classified as "large" or "small" according to their number of students[1]. The technology-oriented innovations were mainly from larger institutions (78 per cent), possibly because they usually have more resources for implementing innovations. A relatively larger proportion (47 per cent) of this group of innovations had a longer length of implementation of more than 1.5 years. In comparison, a smaller proportion (56 per cent) of the non-technology-oriented group was from large institutions, but more were from small institutions (e.g. community colleges). The innovations of this group had been implemented mostly ( 80 per cent) for 1.5 years or less.

\section{Teaching innovations}

\section{Discussion}

The results of this study have unveiled the diversity of teaching innovations in some Asian higher education institutions as well as their educators' perceptions of them. The findings also suggest that the nature of an institution, especially its scale, might shape the adoption of teaching innovations. These findings help to show the formation of innovative strategies for Asian education institutions, particularly for open and distance learning institutions with various scales and development status (Wong and Wong, 2018).

The finding that teaching innovations may have no relationship with the use of technology contrasts with some of the literature which has put the incorporation of the latest technology as the core element - or at least one of the core elements (Zhu et al., 2013) - of teaching innovations (Bruce, 1989). In this study, the results also confirm Zhu's (2013) view that innovations in teaching and learning should not be viewed only from the perspective of the adoption and acceptance of technology. Other relevant factors for conceptualising teaching innovations also include the cultural environment (Zhu, 2013), active learning (Chung and Chow, 2004), open-ended and collaborative learning (Bocconi et al., 2014; Foster and Yaoyuneyong, 2016), the implementation of course design that inspires students to integrate knowledge with practice (Lee, 2011) and student engagement (Bildfell, 2015), in addition to the advancement of knowledge, cognitive development and improved academic performance. Lunde and Wilhite (1996) conceptualised innovative teaching as a cluster of qualities of teachers who are able to interact effectively with learners; teachers' openness to change, being persistence, being reflective, using specific teaching approaches and using disciplineembedded pedagogy. Some of the non-technological elements, such as active learning, collaborative learning, integration of knowledge and practice, stimulation of interests and interactions between students, were mentioned by the interviewees in this study.

In some innovation practices, technology was used to enhance the non-academic aspects, such as student-teacher bonding and interaction. This phenomenon is a synthesis of the two views of the participants, who either emphasised the use of technology to enhance students' cognitive skills and academic performance, or the development of their non-academic aspects through non-technological means. Such practices can also be found in the literature, such as the study by Neo and Neo (2001), which applied multimedia to enhance problem-solving skills and found significant improvements in their students.

The teaching innovations in the Asian education institutions did not necessarily involve the latest educational technologies. Some innovative practices made use of existing

\begin{tabular}{lcc}
\hline Factors & Technology-oriented innovations & Non-technology-oriented innovations \\
\hline Scale of institution & Large: $14(78 \%)$ & Large: $5(56 \%)$ \\
& Small: $4(22 \%)$ & Small: $4(44 \%)$ \\
Length of implementation & $\leqslant 1.5$ years: $9(53 \%)$ & $\leqslant 1.5$ years: $8(80 \%)$ \\
& $>1.5$ years: $8(47 \%)$ & $>1.5$ years: $2(20 \%)$ \\
Notes: ${ }^{\text {a }}$ Large institutions: 10,000 students or above; small institution: below 10,000 students
\end{tabular}

Table X.

Relationships of the teaching innovation with the scale of institutions and length of implementation 
AAOUJ 13,2

188

technology for new contexts in institutions, such as the flipped classroom or use of online teaching materials. This relates to Salmon's (2014) transformative framework for learning innovation, namely, that the choices of where and how to innovate should not be based on "off-the-shelf" strategies or market-led approaches, but on meeting an institution's mission and objectives through its core capabilities and existing strengths.

\section{Conclusion}

This study identified two major ways to innovative teaching as reported by educators in Asia, in terms of whether or not technologies are involved. The technology-oriented approaches were applied and regarded as important in areas such as assisting students' learning and increasing the teacher-student interaction. The importance of the nontechnology-oriented innovations lay in, for example, enhancing students' independent learning ability, creativity and self-reflection, with features such as cross-disciplinary collaboration, creativity, active learning and the facilitation of teaching. The innovations addressed both students' academic and non-academic aspects and teachers' work. The participating educators also recommended improvements for the innovations, such as catering for students' diverse needs and evaluation by different stakeholders. The findings suggest that the characteristics of institutions might be associated with the nature, aims, focuses and evaluations of the innovations.

The teaching innovations identified in this study showed a difference from the prevalent view in the literature that technology is a core element of teaching innovations. The innovations also had a wide variety of aims and directions worthy of development. Therefore, academic learning and performance should not be the only dimensions for judging the effectiveness of teaching innovations. Other aspects of student development, such as the management of emotions, the ability to collaborate with others, problem solving and critical thinking are also important directions for teaching innovations. These competences play an important role in cultivating the twenty-first century competence of individuals (UNESCO, 2016).

As an exploratory study, the results provide potential directions for further investigation. For example, there is a need to gather more details about: educators' views on areas such as active learning and engaging students, and the reasons for smaller institutions using less technology in their teaching innovations. Another area for further study is the evaluation of the effectiveness of teaching innovations, which remains at an immature stage of development. In this research, some of the innovations were not evaluated or evaluated only in terms of their short-term effectiveness. There is a need to evaluate teaching innovations from broader perspectives, and examine how effectiveness may differ in terms of students' background and learning styles as well as teachers' characteristics. Future research on these aspects may allow us to show how contextual and environmental factors influence the effectiveness of teaching innovations, so that they can be better designed and implemented.

\section{Note}

1. With reference to the Carnegie Classification of Institutions of Higher Education (http:// carnegieclassifications.iu.edu/), institutions with 10,000 or more students were classified as "large" and those below 10,000 students were considered "small" as a simplified classification.

\section{References}

Ahmad, T. (2015), "Preparing for the future of higher education", On the Horizon, Vol. 23 No. 4, pp. 323-330.

Altbach, P. (2010), “The Asian higher education century?”, International Higher Education, Vol. 59, pp. 3-5. 
Bildfell, A. (2015), "What is innovative teaching and how can we implement it into our classrooms at the post-secondary level?”, available at: https:/carleton.ca/tasupport/2015/what-is-innovativeteaching-and-how-can-we-implement-it-into-our-classrooms-at-the-post-secondary-level/ (accessed15 December 2018).

Bocconi, S., Kampylis, P. and Punie, Y. (2014), "Creative classrooms: a systemic approach for mainstreaming ICT-enabled innovation for learning in Europe", in Cerone, A., Persico, D., Fernandes, S., Garcia-Perez, A., Katsaros, P., Shaikh, S.A. and Stamelos, I. (Eds), Information Technology and Open Source: Applications for Education, Innovation, and Sustainability, Springer-Verlag, Berlin, pp. 104-120.

Bruce, R. (1989), "Creativity and instructional technology: great potential, imperfectly studied", Contemporary Educational Psychology, Vol. 14 No. 3, pp. 241-256.

Choi, S.P.M., Lam, S.S., Li, K.C. and Wong, B.T.M. (2018), "Learning analytics at low-cost: at-risk student prediction with clicker data and systematic proactive interventions", Educational Technology \& Society, Vol. 21 No. 2, pp. 273-290.

Chung, J.C.C. and Chow, S.M.K. (2004), "Promoting student learning through a student-centred problem-based learning subject curriculum”, Innovation in Education \& Teaching International, Vol. 41 No. 2, pp. 157-168.

Drummond, D., Arnaud, C., Thouvenin, G., Guedj, R., Grimprel, E., Duguet, A. and Petit, A. (2016), "An innovative pedagogic course combining video and simulation to teach medical students about pediatric cardiopulmonary arrest: a prospective controlled study", European Journal of Pediatrics, Vol. 175 No. 6, pp. 767-774.

Evans, K.H., Thompson, A.C., O’Brien, C., Bryant, M., Basaviah, P., Prober, C. and Popart, R.A. (2016), "An innovative blended preclinical curriculum in clinical epidemiology and biostatistics: impact on student satisfaction and performance”, Academic Medicine, Vol. 91 No. 5, pp. 696-700.

Foster, J. and Yaoyuneyong, G. (2016), "Teaching innovation: equipping students to overcome realworld challenges", Higher Education Pedagogies, Vol. 1 No. 1, pp. 42-56.

Harvard Business Review (2017), "Asia: the face of innovation”, available at: https://hbr.org/ sponsored/2017/10/asia-the-face-of-innovation (accessed 15 December 2018).

Hauser, G. and Hauser, R. (2011), "Pedagogy, practice and teaching innovation at Harvard", Harvard Magazine, October, available at: http://harvardmagazine.com/2011/10/analysis-pedagogypractice-and-teaching-innovation-at-harvard (accessed 15 December 2018).

Hazen, B.T., Wu, Y., Sankar, C.S. and Jones-Farmer, L.A. (2012), "A proposed framework for educational innovation dissemination", Journal of Educational Technology Systems, Vol. 40 No. 3, pp. 301-321.

Hofman, R.H., Jansen, E. and Spijkerboer, A. (2011), "Innovations: perceptions of teachers and school leaders on bottlenecks and outcomes", Education As Change, Vol. 15 No. 1, pp. 149-159.

Kampylis, P., Law, N., Punie, Y., Bocconi, S., Brečko, B., Han, S., Looi, C.-K. and Miyake, N. (2013), ICTEnabled Innovation for Learning in Europe and Asia: Exploring Conditions for Sustainability, Scalability and Impact at System Level, Joint Research Centre, European Commission, available at: https://ec.europa.eu/jrc/en/publication/eur-scientific-and-technical-research-reports/ict-enabledinnovation-learning-europe-and-asia-exploring-conditions-sustainability (accessed 15 December 2018).

Lantz, M.E. (2010), "The use of 'Clickers' in the classroom: teaching innovation or merely an amusing novelty?", Computers in Human Behavior, Vol. 26 No. 4, pp. 556-561.

Lee, Y. (2011), "A case study on the effect of teaching innovation on learning effectiveness: using a moderator of 'integrating information technology into teaching'", Journal of Human Resources and Adult Learning, Vol. 7 No. 1, pp. 34-49.

Li, K.C., Ye, C.J. and Wong, B.T.M. (2018), "Learning analytics in higher education institutions in Asia", International Conference on Technology in Education, Hong Kong, pp. 161-170.

Li, K.C., Lee, L.Y.K., Wong, S.L., Yau, I.S.Y. and Wong, B.T.M. (2018), "Mobile learning in nursing education: catering for students and teachers' needs", Asian Association of Open Universities Journal, Vol. 12 No. 2, pp. 171-183. 
AAOUJ 13,2
Lunde, J.P. and Wilhite, M.S. (1996), "Innovative teaching and teaching improvement", in Richlin, L. (Ed.), To Improve the Academy, Vol. 15, New Forum Press and the Professional and Organizational Development Network in Higher Education, Stillwater, OK, pp. 155-167.

Neo, M. and Neo, K.T.K. (2001), "Innovative teaching: using multimedia in a problem-based learning environment", Educational Technology \& Society, Vol. 4 No. 4, pp. 19-31.

OECD (2014), Measuring Innovation in Education: A new Perspective, Educational Research and Innovation, OECD Publishing, Paris, available at: http://dx.doi.org/10.1787/9789264215696-en

Salmon, G. (2014), "Learning innovation: a framework for transformation”, European Journal of Open, Distance and e-Learning, Vol. 17 No. 2, pp. 220-236.

Smith, K. (2011), "Cultivating innovative learning and teaching cultures: a question of garden design", Teaching in Higher Education, Vol. 16 No. 4, pp. 427-438.

UNESCO (2016), "Preparing \& supporting teachers to meet the challenges of 21st century learning in Asia-Pacific: transversal competencies in education policies and practice", UNESCO Asia-Pacific education thematic brief, Bangkok, available at: http://unesdoc.unesco.org/images/0024/002460/2 46052E.pdf (accessed 15 December 2018).

Weller, M. and Anderson, T. (2013), "Digital resilience in higher education", European Journal of Open, Distance and e-Learning, Vol. 16 No. 1, pp. 53-66.

Wong, B.T.M. (2017), "Learning analytics in higher education: an analysis of case studies", Asian Association of Open Universities Journal, Vol. 12 No. 1, pp. 21-40.

Wong, B.Y.Y. and Wong, B.T.M. (2018), "Open and distance learning in Asia: Status and strengths", in Li, K.C., Yuen, Y.S. and Wong, B.T.M. (Eds), Innovations in Open and Flexible Education, Springer, Singapore, pp. 61-72.

Zhu, C. (2013), "How innovative are schools in teaching and learning? A case study in Beijing and Hong Kong”, Asia-Pacific Education Researcher, Vol. 22 No. 2, pp. 137-145.

Zhu, C., Wang, D., Cai, Y. and Engels, N. (2013), "What core competencies are related to teachers' innovative teaching?", Asia-Pacific Journal of Teacher Education, Vol. 41 No. 1, pp. 9-27.

\section{Corresponding author}

T.M. Wong can be contacted at: billywtm@gmail.com

For instructions on how to order reprints of this article, please visit our website: 